\title{
THE CORRELATION BETWEEN SUPERVISION OF HEADMASTER AND INTERPERSONAL COMMUNICATION WITH WORK ETHOS OF THE TEACHER
}

\author{
Murtiningsih ${ }^{1}$, \\ Muhammad Kristiawan', \\ Bukman Lian $^{3 i}$ \\ 1SMP 13 Palembang, \\ Palembang, Indonesia \\ 2Universitas Bengkulu, \\ Bengkulu, Indonesia \\ ${ }^{3}$ Universitas PGRI Palembang, \\ Palembang, Indonesia
}

\begin{abstract}
:
The objectives of this study were to examine 1) the correlation between supervision of headmaster and teachers' work ethos, 2) interpersonal communication and teachers' work ethos, and 3) supervision of headmaster and interpersonal communication with teacher' work ethos. This research was used quantitative descriptive method by using multiple correlation. Data collected by questionnaire, and documentation. Data were analyzed descriptively by using SPSS (version 16.0 for windows. From the research results can be seen that the value of $t$ obtain or Sig. of supervisionn of headmaster was 0.006 whose value is less than $=0.05$. It means that was significant correlation between supervision of headmaster (X1) and work spirit (Y). The value of $t$ obtain or sig. $t$ Interpersonal Communication $(\mathrm{X} 2)$ was 0.023 whose value is smaller than the value = 0.05. This means that there is a significant correlation between Interpersonal Communication (X2) with work spirit (Y). The value of F obtained was 12,960. While the value of significant $F$ is 0,000 , where the value is less than the accuracy value $=0.1$ $(\mathrm{PV}<)$, it means that there is a significant correlation between Supervision of head master (X1), and Interpersonal Communication (X2) with work spirit (Y).
\end{abstract}

Keywords: headmaster supervision, interpersonal communication, work ethos

\section{Introduction}

School is a formal educational institution that organizes teaching and learning activities as an effort to achieve educational goals. The high quality of education is much

${ }^{i}$ Correspondence: email murtiyudhi@gmail.com, muhammad.kristiawan@yahoo.co.id, drbukmanlian@gmail.com 
influenced by the quality of the learning process undertaken by teachers. Teachers as a leading sector in educating students, it is necessary for the guidance of the principal in order to improve the work ethic of teachers to carry out learning activities. This thesis writing begins with the findings of Husni (2014) which states that Teacher Working Ethics at SMK Negeri 1 Lubuk Sikaping is good (85\% of ideal score), Teacher performance in SMK Negeri 1 Lubuk Sikaping is good (81.88\% of score ideal), there is a meaningful relationship between work ethic and teacher performance in SMK Negeri 1 Lubuk Sikaping where the magnitude of correlation coefficient $r$-count $=0.35>$ r-table $=$ 0.306 and significance of correlation coefficient thasil $=3.61>$ ttabel $=2.61$ at the level $99 \%$ confidence.

In addition, the research results Ramezan (2013) states that educational guides must follow the principles of educational supervision and guidance for improvement of educational and learning conditions. They must always be concerned about their plans and activities. Thus, the guidance of education should follow the guidance of supervision and supervision in supervising and supervising, principles of supervision and educational guidance for improving educational and learning conditions. They should always pay attention to these principles in their plans and activities. Thus, due to the importance of adherence and consideration of each principle in the supervision and significant educational guidance, in this paper, it has been attempted to apply the principle of oversight, which can guide the supervisor in the design and implementation of educational supervision.

While Fatmawati (2013) in terms of its working period, PAUD teachers in Kalijambe who have a working period of 0 - 5 years have the highest work ethic, then with a working life of over 10 years, and who have the lowest work ethic is the period of work 6 - 10 years. The findings of Misra (2013), which states that the implementation of the principal's supervision of teachers to develop lesson plans (RPP) has an effect on the improvement of teaching and learning process. Further research results Sumarsono (2011) and Renata et. al. (2018) shows that the supervision of principals, significantly affect the motivation, discipline and performance of teachers. This is also in line with the results of research Ihsanuddin (2012) which shows that; 1) interpersonal communication of grade XI students of SMK Muhammadiyah 3 Yogyakarta is very good 2) there is significant influence of interpersonal communication to student entrepreneur intention, 3) there is significant influence of family environment to interest in berwirausa. These results provide understanding that there is a significant influence of interpersonal communication and family environment variables simultaneously to the student entrepreneurship intention SMK Muhammadiyah 3 Yogyakarta.

Communication that occurs in schools, especially between the principal and teachers, if done well and intensively it will affect the attitude of teachers in carrying out their daily duties, which led to the increase in work ethos at school. Conversely, if the process of communication interaction that occurred in the school was not good, it will bear an apathy attitude. Especially when there is a difference of opinion or conflict between them. If that happens, it can have an impact on the work that is not maximal. Between the two parties need to establish two-way communication or intensive 
reciprocal communication. So that each other has openness and harmonious cooperation between the principal and teachers, so that the goals to be achieved by educational institutions can be achieved.

In general, communication takes place on a reciprocal basis and generates feedback directly in response to a message. Two way communication and direct feedback will make it possible for effective communication. The essence of this interpersonal relationship is when communicating, the principal not only convey the content of the message, but also build a good relationship to the communicant (teacher) as well as the relevant parties in the school. Working ethos needs to be owned by a teacher in order to achieve the standard that has been set, because with this teacher has a very strong spirit to do their work optimally. As suggested by Surya (2004) one of the characteristics of the teacher profile which is estimated in accordance with the future demand facing the 21st century is the teacher who has a strong work ethic. Work ethic is an internal condition that encourages and controls behavior towards the realization of ideal quality of work (Kartini, 2011). Every organization that always wants to go forward will involve members to improve the quality of their work, such as each organization must have work ethic, as well as with teachers as members of the school organization.

Given enough heavy tasks that must be done by a teacher, it is appropriate teachers get a lot of things that can arouse his enthusiasm in work. This is important, because a teacher will produce good performance if they have good competence and have enough work motivation. Various efforts have been made to optimize the teaching and learning process in the classroom by implementing upgrading program to improve teacher competence, introduction of new methods in learning, and improvement and improvement of education facilities and infrastructure.

\section{Working Ethos}

Ethos comes from Greek (ethos) which gives meaning to attitude, character, character and belief in something. Whereas in English terms ethos is defined as the fundamental character or spirit of a culture, various expressions that indicate the belief, custom, or behavior of a community group. Tasmara (2002) explained that in the ethos there is a kind of spirit to perfect everything and avoid any damage so that every job is directed to reduce and even eliminate at all the defects of his work. This is in line with what was stated by Ndara (2002) that work ethic is closely related to work culture, so that will produce productivity and quality of work. A job will be felt more lightly if done with a strong spirit in order to memehuhi work responsibilities carried. Similarly, teachers, if only oriented to a form of commercial effort then they will tend to teach with arbitrary regardless of what learners obtained from the learning that took place. Then the work ethic needs to be owned by a teacher in order to achieve the standards that have been set. This work ethic can be positive or negative so it can affect the organization (Barkah, 2002). 
In line with that presented by Ndara, according to Djohar (2006) work ethic of teachers as a creative self-manifestation measurable from the performance of teachers, know what is done, able to create work without the command of others, immediately switch to another job when completed, able manage time and enjoy work. Through the work ethic of teachers increasingly have a sense of responsibility towards the profession, so that teachers will optimize the achievement of teacher work standards one of them is the professional competency standards of teachers (Hamdani, et. al. 2018) (Andriani, et. al. 2018). According to Anoraga (2006) work ethic is a view and attitude of a nation or people against work. If individuals in the community view work as a noble thing for human existence, then the work ethic will tend to be high. On the other hand, attitudes and views toward work are of low value to life, then the work ethic will necessity be low (Fitria, et al 2017) (Fitria, 2018).

From the above description it is clear that the work ethic is an important thing in possession by every teacher that ultimately leads to a work culture owned by the teacher. If the teacher has a good work ethic then the teacher will always perform their duties optimally. Through the above understanding can be concluded that the work ethic is a set of attitudes or fundamental views that are held by someone in order to improve the quality of life thus affecting the behavior of his work.

\section{Headmaster's Supervision}

Supervision is etymologically derived from the word "super" and "vision" which means seeing and reviewing from above or judging from the top done by the superior to the activities, creativity, and performance of subordinates (Mulyasa, 2000) (Kristiawan, 2019). There are some terms that are almost the same as the supervision even in the implementation of these terms are often used interchangeably. These terms include, supervision, inspection and inspection. Supervision implies an activity to make observations for the work done in accordance with the provisions. The examination is intended to see how the activities carried out have reached the goal. Inspection is intended to know the deficiencies or errors that need to be fixed in a job. According to Sergiovani and Starrat (1993) supervision is a process designed to help teachers and supervisors leam more about their practive; to better able to use their knowledge ang skills to better serve parents and schools; and to make the school a more sffsctive learning community. Supervision is a process specially designed to assist teachers and supervisors in learning the day-to-day tasks at school in order to use their knowledge and ability to provide better service to parents of learners and schools as well as to make the school a better community effective.

According to Gaffar (2007) supervision is to overcome the task problems in the field. Supervision emphasizes professional growth with a core of technical expertise and needs to be supported by professional personality and attitudes. In relation to such guidance material, the foundations of educational supervision are learning technology, curriculum theory, group interaction, counseling, sociology, discipline, evaluation, management, learning theory, history of education, communication theory, personality 
theory, and educational philosophy (Oliva, 2007). In addition, supervision should be a program designed by schools and auxiliary organizations and the provision of education and supported by activities held by the teacher. Supervision is a process designed by schools to advance the quality and quantity of teachers needed to solve problems, in order to achieve school goals. From some opinions and understanding above it can be concluded that the supervision of the principal is not a momentary activity such as inspection, but is a continuous and continuous activity so that teachers are always growing in doing the tasks and able to solve various problems of education and teaching effectively and efficiently

\section{Interpersonal Communication}

Interpersonal communication is described as a communication between two individuals in which the individuals physically interact with each other, giving each other feedback. According to Muhammad (2005), interpersonal communication is a communication that forms relationships with others. These relationships can be classified in several ways including intimate interactions, interrogation social conversations or interviews and interviews. Meanwhile, according to Purwanto (2006), that interpersonal communication is communication that is done between someone with other people in a society and organization, by using certain communication media and can be easy to understand language to reach certain purpose.

Another thing also expressed by Sumarsono (2011), that interpersonal communication is the process of delivering and receiving messages between the sender of the message with the recipient of the message either directly or indirectly. According to Suranto (2011) interpersonal communication is the process of delivering and receiving messages or message sender (Sender) with the receiver of the message (receiver) either directly or indirectly. Patic (2016) The concept of social relationships is initiated for the primary objective of friendship, socialization, enjoyment, accomplishment of a task, or establishing a mutual and respectable relationship. the concept of social relations begins for the primary purpose of friendship, socialization, enjoyment, fulfillment of duties, or the establishment of mutually respectful relationships.

This also (Anne, 2015) states that interpersonal relationship is a driving force in our live. Interpersonal communication is one of the most important in living the life of society. Based on these opinions can be concluded that interpersonal communication is the process of delivering information, thoughts and attitudes certain between two or more people who turn the message either as communicant or communicator with the aim to achieve mutual understanding of the issues to be discussed that eventually changed behavior. 


\section{Research Methods}

The research method is an important factor that is very influential on the results of research. Research activities must follow the steps or work procedures so that in the implementation required certain methods. This study uses quantitative descriptive method by using multiple correlation is a number that shows the direction and strength of the relationship between two independent variables together or more with one dependent variable. Arikunto (2013) said that the quantitative approach is an approach used by researchers in researching by measuring the indicators of the variables so that can be obtained overview and conclusions of research problems. Quantitative approach is a method of solving the problem of the planned and meticulous, with a strictly structured design, systematic data collection is controlled and focused on the preparation of inductively inferred theories in the empirical proving hypothesis. Quantitative approach is an effort to measure the variables that exist in the study to then sought the relationship between these variables. This research uses qualitative method with correlational research type because this study aims to see the relationship between one variable with another. Data analysis using SPSS software version 16 assistance.

\section{Results and Discussion}

The following discussion is based on statistical analysis of partial correlation, correlation correlation and multiple linear regression correlation, and effort of deepening of each variable by using result of analysis that have been processed.

\section{a. Principal Supervision Relation with Teacher Working Ethos}

Inferential analysis shows that partially the principal supervision variables have significant relationship with the performance of teachers of West Ilir District II Palembang, where and the partial test results (t-test) significance t-value 0.006. And on the descriptive analysis also obtained more results and $50 \%$ of respondents stated that Supervision Principal SMP District Ilir West II Palembang is very good, but in some questions there are still respondents who stated very well less than $50 \%$, it can be interpreted that the provision supervision by the principal has not been done thoroughly for each dimension.

The principal or administrator is the highest role holder in a school institution. the successful principals, the achievement of school goals, and the goals of the induviduals within the school environment, must understand and master the role of the organization and the cooperative relationship between induvidu. Permendiknas Number 13 Year 2007 states that a Principal should master the Principal Competency Standards consisting of: personality competence, managerial competence, supervision competence, entrepreneurial competence and social competence. The elaboration of the competence of supervision is essentially academic supervision where the steps taken are to plan the academic supervision program in order to increase the professionalism 
of the teacher, to supervise academic of the teacher by using the appropriate approach and supervision technique and to follow up the academic supervision result to the teacher in order to increase the professionalism.

This is supported also by Maria (2015) which states that nowadays, School goes through the moments of change and transformation. As such, more studies are needed about the crossroads of teachers' supervision and evaluation. It is essential to take into account heterogeneous contexts of some teachers, the Master's or Doctoral Degree, as in this study's specific case, and the many other teachers who maintain their nuclear references Bachelor's Degree, concluded years ago. It is in the convergence of this teachers' supervision and evaluation are at stake, uniting Schools and Universities in the same unique task of improving the quality of education. Today. School passes moments of change and transformation. Thus, more research is needed on the intersection of teachers' supervision and evaluation. It is important to consider the heterogeneous context of some teachers - researchers who invest in specialized training, Masters or Doctorate, as in the special case of this study, and many other teachers who maintain their nuclear reference, their Bachelor's Degree, concluded several years ago. In the convergence of teachers' diversity, present and future teacher oversight and evaluation are at stake, bringing School and University together in the same unique duty to improve the quality of education.

The guidance of the principal in the planning of enrichment and remedial programs is carried out in meetings with the classroom teacher. In addition, this can be accomplished through coordination with the libraries to provide books and equipment needed by teachers in the learning process, and the principal provides school funding for teaching resource supplies used by teachers teaching in the classroom. Academic supervision in teacher's teaching planning still needs to be improved and continues to be done by the principal so that its implementation can reach a better level to improve the professionalism of teachers.

\section{b. Interpersonal Communication Relationship with Teacher Working Ethos}

The results of inferential anailsis show that partially interpersonal communication has a very significant relationship with Working Ethics of junior high school teacher of Ilir Barat II Palembang, where the partial test result (t-test) significance $t$ is 0,023 . One supporting indicator for every human being to interact with fellow beings, in this case is interpersonal communication. Taylor (1999) defines interpesonal communication as a communication between two people in a face-to-face manner that is spontaneous, informal, mutual reciprocal feedback and participation in a flexible role.

These technical matters, especially the activities of managing and implementing teaching and learning interactions. In the education process we often encounter failures, this is usually due to weak communication system used. For that, educators need to develop effective communication patterns in the learning process. Educational communication that is meant is the relationship or interaction between educators with learners at the time of the learning process takes place or with another term that is an active relationship between educators with learners. 
In addition, too (Deepa, 2009) communication plays a crucial role in the functioning of organizations. In fact, what an organization requires mainly communication. It is an inseparable, essential and continuous process just like the circulatory system in the human body. Communication plays an important role in the functioning of the organization. Actually, what the organization needs is mainly communication. It is an inseparable, important and continuous process like the circulatory system in the human body.

\section{c. Principal Supervisory and Interpersonal Communication Relationship with Teacher Working Ethos}

The analysis results show that the value of $\mathrm{F}$ hitunga is 14.871 . While the value of significant $\mathrm{F}$ is 0,000 , where the value is less than the accuracy value $=0.1(\mathrm{Pv}<)$, it means that there is a significant relationship between Principal Supervision (X1), and Interpersonal Communication (X2) on Teacher Working Ethos (Y). There are some terms that are almost the same as the supervision even in the implementation of these terms are often used interchangeably. These terms include, supervision, inspection and inspection. Supervision implies an activity to make observations for the work done in accordance with the provisions. The examination is intended to see how the activities carried out have reached the goal. Inspection is intended to know the deficiencies or errors that need to be fixed in a job. Supervision is a process specially designed to assist teachers and supervisors in learning the day-to-day tasks at school in order to use their knowledge and ability to provide better service to parents of learners and schools as well as to make the school a better community effective. The key word of the supervisory exercise is providing services and assistance. A similar opinion was expressed by Fathurrohman and Suryana (2011) and Kristiawan, et al (2019) that supervision as a grant provided by the principal to carry out the assessment and supervision of the technical aspects of education and administration in the form of providing guidance and examples about the teaching implementation of teachers so as to improve and improve teacher performance in carry out the main task. Interpersonal communication is the process of delivering certain information, thoughts and attitudes between two people or more that there is a change of messages both as communicant and communicator with the aim to achieve mutual understanding of the issues to be discussed that eventually changed behavior.

\section{Conclusion}

There is a significant correlation between Principal Supervision (X1) and Teacher Working Ethics (Y) or it can be interpreted that Ho is rejected and Ha accepted so that the hypothesis says that "Principal Supervision relates to Teacher Working Ethics SMP Kecamatan Ilir Barat II Palembang is significant. There is a significant relationship between Interpersonal Communication (X2) with Teacher Working Ethics or it can be interpreted that Ho is rejected and Ha accepted so that the hypothesis that Interpersonal Communication with Teacher Working Ethics of SMP Ilir Barat II Palembang is 
significant. There is a significant relationship between Principal Supervision (X1), and Interpersonal Communication (X2) on Teacher Working Ethos (Y).

\section{References}

Andriani, S., Kesumawati, N., \& Kristiawan, M. (2018). The Influence of the Transformational Leadership and Work Motivation on Teachers Performance. International Journal of Scientific \& Technology Research Volume 7, Issue 7, July 2018

Anne, M. N. (2015). The Importance of Communiation in Interpersonal Relationship. Adekunle Ajasin University, Akungba- Akoko, Nigeria

Anoraga, P. (2006). Psikologi Kerja [Work Psychology]. Jakarta:PT. Rineka Cipta.

Arikunto, S. (2013). Prosedur Penelitian Suatu Pendekatan Praktek [Research Procedure, A Practical Approach]. Jakarta: Rineka Cipta.

Barkah. 2002. Implementasi Etos Kerja dalam Organisasi [The Implementation of Work Ethos on Organization]. Jurnal Universitas Sebelas Maret.

Deepa. 2009. Interpersonal Communication: Lifeblood of an Organization of Management, Jaipuria Institute of Management, Lucknow, India

Djohar (2006). Etos Kerja Pendidik [Teachers' Work Ethos]. Jakarta: Rineka Cipta.

Fathurrohman, P. (2011). Supervisi Pendidikan dalam Pengembangan Proses Pengajaran [Educational Supervision on Developing Instructional Process]. Bandung: Refika Aditama.

Fatmawati, V. (2013). Etos Kerja Guru Pendidikan Anak Usia Dini di Kecamatan Kalijambe Kabupaten Sragen Ditinjau dari Tingkat Pendidikan dan Masa Kerja Tahun Pelajaran 2012/2013 [Work Ethos of Kindergarten Teachers]. Jurnal Universitas Muhammadiyah Surakarta.

Fitria, H. (2018). The Influence Of Organizational Culture And Trust Through The Teacher Performance In The Private Secondary School In Palembang. International Journal of Scientific \& Technology Research, 7(7).

Fitria, H., Mukhtar, M., \& Akbar, M. (2017). The Effect of Organizational Structure And Leadership Style on Teacher Performance In Private Secondary School. IJHCM (International Journal of Human Capital Management), 1(02), 101-112.

Gaffar. (2007). Supervisi di Bidang Pendidikan [Supervision on Education]. Bandung: Alfabeta.

Hamdani., Kesumawati, N., \& Kristiawan, M. (2018). The Influence of Teachers' Work Motivation and Principals' Managerial Competence on Teachers' Performance. IOSR Journal of Humanities and Social Science (IOSR-JHSS) Volume 23, Issue 9, Ver. 1 (September. 2018) 72-76

Husni, I. (2014). Hubungan Etos Kerja dengan Kinerja Guru di SMK Negeri 1 Lubuk Sikaping [The Correlation of Work Ethos and Teachers' Performance]. Jurnal Univeristas Negeri Padang.

Ihsanuddin. (2012). Pengaruh Komunikasi Interpersonal Dan Lingkungan Keluarga Terhadap Intensi Berwirausaha Siswa SMK Muhammadiyah 3 Yogyakarta [The Influence of 
Interpersonal Communication and Environment toward Entrepreneurship Skill]. Jurnal Universitas Negeri Yogyakarta.

Kartini, K. (2011). Etos Kerja Karyawan [Work Ethos of Staff]. Bandung: Alfabeta.

Kristiawan, M., Yuniarsih, Y., Fitria, H., \& Refika, N. (2019). Supervisi Pendidikan [Educational Supervision]. Bandung: Alfabeta

Maria. (2015). Interpersonal Communication: Lifeblood of an Organization. Department of Management, Jaipuria Institute of Management, Lucknow, India.

Mulyasa, E. (2007), Menjadi Kepala Sekolah Profesional [Being Professional Principal]. Bandung, PT. Remaja Rosdakarya.

Muhammad A. (2017). Pengaruh Komunikasi Interpersonal Guru Terhadap Motivasi Berprestasi dalam Mewujudkan Kinerja Guru [The Influence of Interpersonal Communication and Achievement Motivation toward Teachers' Performance]. Tesis Pascasarjana Universitas Garut.

Ndara, M. (2002). Etos Kerja dan Budaya di Lingkungan Sekolah [Work Ethos and Culture in School]. Unpublished Journal.

Olivia S. (2007). Peningkatan Nilai Supervisi [Upgrading Score of Supervision]. Jakarta: Rineka Cipta.

Patic. (2016). Human Communication and Effective Interpersonal Relationships: An Analysis of Client Counseling and Emotional Stability. School of Education, Howard University, Washington, DC 20059, USA

Ramezan, J. (2013). Principles for Educationa Supervision and Guidance Department of Psychology, Karaj Branch, Islamic Azad University.

Renata, R., Wardiah, D., \& Kristiawan, M. (2018). The Influence of Headmaster's Supervision and Achievement Motivation on Effective Teachers. International Journal of Scientific E Technology Research Volume 7, Issue 06, June 2018.

Sergiovani \& Starrat. (1993). Supervision Process Designed to Teacher. State University of New York at Albany.

Sumarsono. (2011). Pengaruh Supervisi, Motivasi dan Kedisiplinan terhadap Kinerja Guru [The Influence of Supervision, Motivation and Discipline towards Teachers' Performance]. Jurnal Univeristas Negeri Semarang.

Suranto. 2011. Komunikasi Interpersonal Karyawan pada Perusahaan [Interpersonal Communication of Staff in Company]. Unpublished Journal.

Surya M. (2004). Implementasi Keterampilan Pedagogik Pendidik [The Implementation of Teachers' Pedagogy]. Jakarta: Rineka Cipta.

Tasmara, T. (2002). Membudayakan Etos Kerja Islami [Enculture Islamic Work Ethos]. Jakarta: GemaInsani Press.

Taylor. (1999). The Impact of Instructional Supervision on Academic Performance of Secondary School Students in Nasarawa State, Nigeria. Federal Road Safety Commission (FRSC), RS4.35 Nassarawa Eggon Unit Command, Nasarawa State, Nigeria. 

will be applied to their work. Under the terms of this license, no permission is required from the author(s) or publisher for members of the community to copy, distribute, transmit or adapt the article content, providing a proper, prominent and unambiguous attribution to the authors in a manner that makes clear that the materials are being reused under permission of a Creative Commons License. Views, opinions and conclusions expressed in this research article are views, opinions and conclusions of the author(s). Open Access Publishing Group and European Journal of Education Studies shall not be responsible or answerable for any loss, damage or liability caused in relation to/arising out of conflicts of interest, copyright violations and inappropriate or inaccurate use of any kind content related or integrated into the research work. All the published works are meeting the Open Access Publishing requirements and can be freely accessed, shared, modified, distributed and used in educational, commercial and non-commercial purposes under a Creative Commons Attribution 4.0 International License (CC BY 4.0). 